\title{
Men Can/Can Men Change?
}

\author{
By \\ Gabriella Nilsson \& David Gunnarsson
}

\begin{abstract}
Gender issues are often brought to the fore in times of social change. This certainly seems true regarding current debates on what it means to be a man today. In an international context, the past decade has seen a change in political discourse, with the rise of nationalist movements in many parts of the world, as well as the (lack of) response to global challenges, such as climate change and refugee crises. The image of a conservative, narrow-minded, violent and misogynist masculinity is emerging. Increasingly during the 2010 s, the so-called "anti-gender movement" declared that gender perspectives were ideological; a Trojan horse with which, not least, the "family" was threatened. Attacks against feminism have been radicalised and have joined causes with racist movements and "climate deniers" (Kvinna till Kvinna 2019, Gunnarsson Payne 2020). Highlighted in relation to concepts and phenomena such as "alternative facts", "fake news", "rape culture", and "internet trolls", masculinity stands out as "toxic" - to men themselves, to women, and to the globe.

To escape this toxic masculinity, masculinities embracing their "softer", more vulnerable, sides appear, and the binary gender order is criticised, with critics demanding a change in our views of what it means to be a man. One of the most prominent debates concerns men's "emotional illiteracy" and incapacity to display vulnerability (Pease 2012:126). This is also connected to ideas that self-restraint and self-control are important features needed in order to be accepted as a man, resulting in a "fear of falling" (Ekenstam 1998). However, much of the earlier research has ignored both practices of 'softer' forms of masculinity as well as how emotions inform all social action (de Boise \& Hearn 2017). The contributions to this thematic issue concerning masculinity all touch on the issue of "men can/can men change?" A recurring theme is how men in different contexts and in different ways strive to be "non-toxic", how men try to define and express what a "good masculinity" could or should be.
\end{abstract}

Nilsson, Gabriella \& David Gunnarsson: "Men Can/Can Men Change?", Culture Unbound, Volume 12, issue 3, 2020: 436-443. Published by Linköping University Electronic Press: http://www.cultureunbound.ep.liu.se 
For decades, research on men and masculinity has embraced a critical, pro-feminist perspective on the study of men (Hearn 1998). This is due to the extensive work of researchers such as Jeff Hearn and Raewyn Connell, among others, who explicitly criticised the often anti-feminist tendencies within previous research on men (Hearn 1998, Connell 1999).

When Connell, as early as 1995, used masculinity in the plural, as masculinities, this was ground-breaking for the study of men from a constructivist perspective. Instead of assuming that masculinity is constructed only in relation to femininity, Connell showed how relationships and hierarchies within the gender, between various masculinities, were important. This did not mean that Connell turned a blind eye to how the gender order in a radical way arranged men and women hierarchically in terms of superiority and subordination. By putting masculinity in the plural and thus acknowledging a variety of masculinities, Connell wanted to open the possibility of understanding the complex contexts within which masculinity is constructed-and to open the hypothetical possibility of change. Nevertheless, it is, above all, this plural form that has come into question. Critics say that rather than allowing for complexity, the plural form signals that it is possible to identify different, discernible types of masculinities, and by extension groups of men, with specific characteristics (Hill 2007). This has led Connell to emphasise repeatedly that different masculinities should not be equated with types of men (Connell \& Messerschmidt 2005, Messerschmidt 2018).

The concept that Connell is best known for, but also the one that has attracted the most criticism, is that of hegemonic masculinity. The term aims to describe how a certain expression of masculinity in a given context is elevated and comes to dominate other ways of constructing masculinity. This refers to how men who construct masculinity in different ways are forced to relate to each other, how they form alliances by enclosing, excluding, harassing, and exploiting each other and are given or deprived of power in different ways (Connell 1996). The concept of hegemonic masculinity presumes the subordination of non-hegemonic masculinity, a power relation based on consent, achieved through culture and persuasion, rather than through force (Connell and Messerschmidt 2005, Nilsson 2013). Since it was first developed, the theory of hegemonic masculinity has been employed, criticised and/or elaborated by countless masculinity scholars.

A critique has been directed at the perceived lack of concepts with which to describe "good" men, and the positive changes that many men today exhibit in more gender-equal societies (Anderson 2009, Anderson \& McCormack 2018, Berggren 2020). Anderson argues that the changes in masculinity among many men today are so radical, not least in terms of decreased homophobia, that the theory of hegemonic masculinity has become insufficient. To counter the lack of concepts within Connell's theory to describe men who are, or strive to be, 
gender equal, concepts such as "including masculinity", "positive masculinity", "softening masculinity", and "caring masculinity" have been suggested (Berggren 2020; de Boise \& Hearn 2017). A critique of this perspective is that a change such as reduced homophobia should not only be understood as a progressive shift in gender relations. It can also be a resource for privileged men to present themselves as better and more aware than other men, and can thus contribute to a new hegemony where hierarchies are reproduced (Berggren 2020, Bridges \& Pascoe 2014; de Boise 2015).

\section{A Particular Swedish Context}

In 1995, the United Nation's Fourth World Conference on Women in Beijing appointed Sweden as the world's most gender-equal country, which coincided with Sweden's entry to the European Union. This meant that when Sweden had to form itself as an EU-member and needed a profile that would distinguish it from the other member states, gender issues and gender equality seemed an easy choice (Towns 2002). A grand narrative of Sweden as a gender-equal country was made possible, allowing even, for example, the male dominated cultural sector in Sweden to appear to be champions of gender equality (Hudson \& Sandberg 2019). Concerning men and nationality, gender equality almost becomes a trait inherited by parentage, along with cultural citizenship (jus sanguinis) in Sweden. The problem of men and gender equality in Sweden thus boils down to something that was observed already in the 1980s, namely that Swedish men generally are gender equal in principle (Jalmert 1983; Mellström 2006). Figures show, however, that this does not self-evidently translate into practice. For example, statistics from 2019 show that men were responsible for 30\% of parental leave days used that year.

The in-principle-man has paved way for postfeminist thoughts in Sweden. Although postfeminism can be understood in plural and refer to differing phenomena and perspectives (see Gill 2007; Rivers 2017 for examples), we use it here in the sense of viewing feminism as a finished feat, made superfluous by the achievements of feminist movement(s) (Goedecke 2020). Even though feminism might still be perceived as important, it is 'post' because it is no longer needed as a social and political movement. Gender equality is almost viewed as a genetic trait in white Swedishness, in relation to which immigrants in general, and Muslim men in particular, are often viewed as the bearers of gender inequality (Farahani 2012; Gottzén \& Jonsson 2012; Gunnarsson 2016; Khosravi 2009). Thus, displacement of gender inequality is brought about by a simultaneous recognition of feminism and a denial of needing it oneself. As the gender studies scholar Klara Goedecke explains in this issue, "Thus, postfeminism does not constitute a rejection of 
feminism. Instead, postfeminism is entangled with feminism in processes of 'incorporation, repudiation, commodification"' (Goedecke 2020: xx). In other words, feminism can be superficially embraced by men without challenging patriarchy.

\section{Researching "Good Men"}

Thus, one might ask how much change really has taken place. Many have long pointed out the problematic in that masculinity research tends to focus on good masculinity and not on bad masculinity. While the need for changed masculinities is now articulated to a higher degree, there is a lack of answers as to how that can be achieved. Among others, Lucas Gottzén observes that violent men are generally left out of the scope of research interest, whereas studies of fatherhood, work, and similar studies of "good men" are still conducted (Gottzén 2014).

There are signs that in recent decades there has been a positive change in masculinity norms in Sweden, insofar as men now have a different view of what everyday life and family life should look like. There is a general perception among men that both parties in a relationship should take responsibility for the home and childcare. Sexism and homophobia are questioned in public debate, etc.

However, masculinity researcher Thomas Johansson emphasizes that the image of a "new masculinity" clashes with reports of violence and sexual abuse, and that it is often difficult to combine observation of positive changes with statistics on the prevalence of violence. Signs that male norms are changing are seen in parallel with inequality remaining and taking on new forms (Johansson 2014). This has been made clear by the Me Too movement. When the psychologist Lars Jalmert, as early as 1983, coined the term "in-principle-man", it meant that attitudes to gender equality among men in Sweden were generally positive, but that in practice there were always perceived individual reasons why one did not live a gender-equal life oneself (SOU 2014: 71). Additionally, as it has since been seen, the notion of the "gender-equal" Swedish man is not necessarily effective for making real demands on men to stop using violence in relationships. Neither has it been effective for engaging non-violent men in work to counteract the violence of other men (Nilsson \& Lövkrona 2020).

In a recent special issue of the Swedish journal, Socialmedicinsk tidskrift on the theme of Masculinity in Change, the editors Tobias K. Axelsson and Tomas Wetterberg stress the importance of not reading the word "change" in a purely positive sense. Though changes in masculinity are often automatically considered as progressive and moving increasingly towards gender equality, Axelsson and Wetterberg point out that change can also mean a deterioration that causes 
significant suffering and prevents a shift towards gender equality and ecological sustainability, among other things (Axelsson \& Wetterberg 2020).

Although, paradoxically, we still know very little about whether gender equality actually reduces men's violence, it seems reasonable that changing masculinity leads to a reduced "need" to use violence. However, the reverse effect is also possible, that society's "demands" for gender equality can be a cause of violence, that violence becomes a way of forcing women back into a subordinate position when other means of maintaining men's superiority are lacking (SOU 2014: 71, Gottzén 2014, Ericsson 2020). An extreme example, and an increasing problem according to the Swedish Defence Research Agency, are the so-called incels, heterosexual men who live in "involuntary celibacy", as a result of what they experience as illegitimate rejection by women. The incel movement developed on the internet in the 2000s and dozens of deadly attacks on women and "popular" men in the world have, since then, been carried out by individuals who identify with the views of incels (Fernquist et al 2020).

Do we even, really, want a changed masculinity? Is society ready to give up the ability of "strong" men to use (good) violence? Can we even imagine gender without violence? These rhetorical questions are posed by Gabriella Nilsson and Inger Lövkrona, in their book on the culturally constructed connection between gender and violence, Våldets kön (The gender of violence 2015/2020). Thus, we can conclude that "change" is not self-explanatory, but rather a politically and normatively charged concept (Axelsson \& Wetterberg 2020).

As a consequence, it is reasonable to ask whether men can be feminists or if men and feminism are an inescapable contradiction? Jeff Hearn, for one, has argued for the use of the term pro-feminist instead of feminist, to call attention to the fact that, regardless of how gender-equal individual men are, they still benefit from the unequal gender order (Hearn 1998; Connell 1999). For the same reason, it is problematic to distinguish toxic masculinity from non-toxic masculinity. The metaphor of toxicity risks portraying men as victims and thereby diminishing men's responsibility for both their actions and their patriarchal dividend (Berggren 2020, Connell 1999). But if the position as man and feminist is a "borderland position", as stressed by Egeberg Holmgren (2011:13), where does this leave a special issue on masculinity? Can men change, or can they not? Perhaps a solution is to insist on a "killjoy" perspective being central to men's feminist engagement, promoting a "chafing masculinity", where men remain where it chafes without trying to deny or escape their sexism and privileges even after they have defined themselves as feminists, or started working actively with feminist politics (Gottzén 2019). It is from such a killjoy perspective that we invite you to take part of the contributions to this special issue. 


\section{Issue Overview}

This special issue contains six articles written by Swedish scholars in ethnology, gender studies, history, sociology, and food studies. They all touch on how masculinity is done, or perceived to be done, in relation to dichotomies such as good/bad, equal/unequal, and strong/vulnerable. In some articles, experiences of being a feminist or partaking in feminist activities become ways of trying out a new masculinity on the micro level. A recurring strand in these contributions is discussions on gender equality and the emotions it brings about in the specific context of Swedish society, both contemporary and historical.

Gender studies scholar Klara Goedecke (Stockholm University) explores how the media's representations of men's intimacy and friendships between men, in an age of postfeminism, are gendered, sexualised, classed and, to some extent, racialised and ageist. These power relations inform the discourses through which the men portrayed are understood. What is at stake is the use of a vocabulary that would activate a discussion on inequalities, this is hindered by the individualisation and neo-liberalisation that goes along with postfeminism.

The sociologist Kalle Berggren (Stockholm University) addresses the issue of men and feminism by analysing lived-experience descriptions in books about men from 2004 to 2015. He identifies a range of emotions-for example, positive ones such as relief or negative emotions such as shame and frustration-which are central to how men are affected by feminism. Loss and mourning are also discussed in Berggren's article, as well as in the ethnologist Silow Kallenberg's (Södertörn University) contribution, which is the only article which departs from women's views on masculinity. This auto-ethnographic piece follows the loss of young male friends, and is based upon interviews with the mother, sister, and girlfriend of the prematurely departed. The discussion revolves around protest masculinity and understanding the narrative elements of making sense of premature death.

How housekeeping is managed is the theme of both historian Robin Ekelund's (Malmö University) and the food studies scholar Nicklas Neuman's (Uppsala University) articles. Their empirical results show how the interviewed men engage in what they perceived as pro-feminist everyday activities, managing the household in a gender-equal manner by means of foodwork or by taking domestic responsibility in other ways. The awareness of the need for gender equality is linked to microlevel changes, such as having children and thus embarking on a reflexive, political journey which might bring about a sense of dislocation. In other words, Ekelund and Neuman engage in desirable forms of masculinity in Swedish society and how these (new?) expectations are handled on an individual level.

Ethnologist Kristofer Hansson (Malmö University) looks back at the negotiations on gender equality in Sweden during the 1970s and the new forms of masculinity which arose about, for example, new fatherhood (parallel with 


\section{Culture Unbound}

Journal of Current Cultural Research

Neuman). New psychological knowledge meant that masculinity at the time was viewed as a part of a crisis of men, and men's individual crises. This is taken as a starting point for discussing how identity could be formed in relation to these crises.

Gabriella Nilsson is an associate professor in Ethnology at Lund University. Her research interest primarily concerns issues of power, addressed in studies on violence, child health and aging. She is a co-editor of the recently published book Rape Narratives in Motion (Palgrave Studies in Crime, Media and Culture, 2019). Presently her research is conducted within the project "Influencer Lifeworlds. New work in a changing time". Email: gabriella.nilsson@kultur.lu.se

David Gunnarsson is a senior lecturer in Ethnology at Sodertorn University. His research interests concern intersections of national identities (mainly nation, religion and gender) and social participation of refugees. Currently, he is involved in the project Resiliency, Mental Health and Social Participation among Refugees (RMSR) at the Swedish Red Cross University College, Flemingsberg. Email: david gunnarsson@sh.se

\section{References}

Anderson, Veanne N. (2009): "What's in a label? Judgments of feminist men and feminist women", Psychology of Women Quarterly, 33(2): 206-215.

Anderson, Eric (2009): Inclusive masculinity: The changing nature of masculinities. New York: Routledge.

Anderson, Eric, \& Mark McCormack 2018: "Inclusive masculinity theory: Overview, reflection and refi-nement". Journal of Gender Studies 27(5): 547-561.

Axelsson \& Wetterberg (2020): Från något till synes stabilt och välbekant till något där konturerna bara skymtar. Socialmedicinsk tidskrift, 97(2): 170-176.

Berggren, Kalle (2020): "Maskulinitetsteorier i förändring: nya begrepp, nya tolkningar". Socialmedicinsk tidskrift, 97(2): 187-198.

Bridges, Tristan, \& C. J. Pascoe (2014): "Hybrid masculinities: New directions in the sociology of men and masculinities". Sociology Compass 8(3): 246-258.

Connell, Raewyn W. (1999): Maskuliniteter. Göteborg: Daidalos.

Connell, Raewyn W. \& James W. Messeschmidt (2005): Hegemonic Masculinity. Rethinking the Concept. Gender \& Society, 19(6): 829-859.

de Boise, Sam. (2015): “'I'm not homophobic, 'I've got gay friends': Evaluating the validity of inclusive masculinity". 18(3): $318-339$

de Boise, Sam \& Jeff Hearn (2017): Are men getting more emotional? Critical sociological perspectives on men, masculinities and emotions. The Sociological Review, 65(4): $779-796$

Egeberg Holmgren, Linn (2011): IngenMansLand: om Men and Masculinities män som feminister, intervjuframträdanden och passerandets politik. Diss. Uppsala: Uppsala universitet

Ekenstam, Claes (1998): Rädd att falla. Studier i manlighet. Stockholm: Gidlunds. 


\section{Culture Unbound}

Journal of Current Cultural Research

Ericsson, Sanna (2020): Reaching for Equality: Essays in Education and Gender Economics, Lund: Lund University.

Farahani, Fataneh (2012): "Diasporic Masculinities: Reflections on Gendered, Raced and Classed Displacements". Nordic Journal of Migration Research, 2(2): 159-166.

Fernquist, Johan, Pelzer, Björn, Cohen, Katie, Kaati, Lisa \& Akrami, Nazar (2020): "Hope, cope \& rope-Incels i digitala miljöer". Totalförsvarets forskningsinstitut, FOI Memo 7040.

Gill, Rosalind (2007): "Postfeminist Media Culture. Elements of A sensibility". European Journal of Cultural Studies, 10: 147-166.

Goedecke, Klara (2020): "Walk the talk: Men's friendships, progressiveness and postfeminism in Swedish television". This issue.

Gottzén, Lucas (2014): Män, våld och jämställdhet. I: Män och jämställdhet. SOU 2014:6, pp. 521-575.

Gottzén, Lukas (2019): Av det känsligare slaget. Män och våld mot kvinnor. Göteborg/ Stockholm: Makadam.

Gottzén, Lukas \& Rikard Jonsson (2012): Andra män. Maskulinitet, normskapande och jämställdhet. Malmö: Gleerups.

Gunnarsson, David (2016): Gäst i Sverige: Sanningsregimer, villkorade själv(re) presentationer och nationell tillhörighet vid moskévisningar i Stockholm. Diss. Stockholm: Stockholms universitet.

Gunnarsson Payne, Jenny (2020): "Conflicts and alliances in a polarized world. Baltic Worlds", xiii (1), Special issue.

Hearn, Jeff (1998): The violences of men. How men talk about and how agencies respond to men's violences to women. London, Thousand Oaks, New Delhi: Sage Publications.

Hill, Helena (2007): Befria mannen! Idéer om förtryck, frigörelse och förändring hos en svensk mansrörelse under 1970- och tidigt 1980-tal. Umeå: h:ström - Text \& kultur.

Hudson, Christine \& Linda Sandberg (2019): "Narrating the Gender-equal CityDoing Gender-equality in the Swedish European Capital of Culture Umeå 2014". Culture Unbound. Journal of Current Cultural Research, 11(1): 30-52.

Jalmert, Lars (1983): Om svenska män. Fostran, ideal och vardagsliv: en rapport. Arbetsmarknadsdepartementet. Stockholm: Liber Förlag.

Johansson, Thomas (2014): "Maskuliniteter i förändring. Män och jämställdhet" SOU: 2014,6 , pp. 347-382.

Khosravi, Shahram (2009): "Displaced masculinity: gender and ethnicity among Iranian men in Sweden". Iranian Studies, 49(4): 591-609.

Kvinna till kvinna (2019): The fierce and the furious. Feminist insights into the anti gender narratives and movement. Griffon, Lucille, EuroMed Rights, Pruth, Charlotte \& Johansson, Maria. The Kvinna till Kvinna Foundation. Rapport 2019.

Mellström, Ulf (2006): "Nytt faderskap i skärningspunkten mellan produktion och reproduktion?" Socialvetenskaplig tidskrift, 13(2): 114-129.

Messerschmidt, James W. (2018): Hegemonic masculinity: Formulation, reformulation, and amplification. Lanham, MD: Rowman \& Littlefield Publishers

Nilsson, Gabriella (2013): "Balls Enough: Manliness and Legitimated Violence in Hell's Kitchen”. Gender, Work \& Organization, 20(6):647-663.

Nilsson, Gabriella \& Inger Löfkrona (2020): Våldets kön. Kulturella föreställningar, funktioner och konsekvenser. Lund: Studentlitteratur.

Pease, Bob (2012): “The politics of gendered emotions. Disrupting men's emotional investment in privilege". Australian Journal of Social Issues, 47(1): 125-142.

Rivers, Nicola (2017): Postfeminism(s) and the Arrival of the Fourth Wave. SpringerLink.

SOU 2014:71. "Ett jämställt samhälle fritt från våld. Utvärdering av regeringens satsningar 2010-2014" (2014). 